\title{
Genotyping Xylella fastidiosa in Rabbiteye blueberry in Louisiana, USA
}

\author{
Mary Helen Ferguson $(\mathbb{D} \cdot$ Christopher A. Clark $(\mathbb{D})$ \\ Barbara J. Smith $(\mathbb{D}$
}

Accepted: 15 May 2020 / Published online: 8 June 2020

(C) The Author(s) 2020

\begin{abstract}
Rabbiteye blueberry (Vaccinium ashei= $V$. virgatum) comprises much of the blueberry acreage in the southeastern USA states of Louisiana and Mississippi. Three genotypes of $X$. fastidiosa were identified from rabbiteye blueberry in Louisiana by multilocus sequence typing. A genotype that was found at two orchards, sequence type (ST) 42, was identical to one previously found in southern highbush blueberry in Georgia and two non-blueberry native species in Texas. Two newly identified genotypes shared most alleles with $X$. fastidiosa strains considered, like ST 42, to be part of a group that is believed to have resulted from recombination between $X$. fastidiosa subsp. multiplex and subsp. fastidiosa. These two genotypes each also had one newly identified allele. This work suggests that a narrow range of $X$. fastidiosa genotypes infect
\end{abstract}

\section{H. Ferguson $(\bowtie) \cdot C$. A. Clark}

Department of Plant Pathology and Crop Physiology, Louisiana State University Agricultural Center, 302 Life Sciences Building, Baton Rouge, LA 70803, USA

e-mail: mhferguson@agcenter.lsu.edu

\section{B. J. Smith}

Thad Cochran Southern Horticulture Laboratory, U.S. Department of Agriculture, Agricultural Research Service, P.O. Box 287,

Poplarville, MS 39470, USA

Present Address:

M. H. Ferguson

Southeast Region Office, Louisiana State University Agricultural Center, 21549 Old Covington Highway, Hammond, LA 70403, USA rabbiteye blueberry in Louisiana but that rabbiteye blueberry may serve as an alternative host for $X$. fastidiosa strains that infect more susceptible southern highbush cultivars.

Keywords Xylella fastidiosa B Bacterial leaf scorch . Blueberry $\cdot$ Vaccinium $\cdot$ Multilocus sequence typing

Xylella fastidiosa Wells et al. has been verified as the cause of bacterial leaf scorch of southern highbush blueberry (Vaccinium corymbosum interspecific hybrids) and has been detected in rabbiteye blueberry (V. ashei Reade $=V$. virgatum Aiton) in the southeastern USA in Alabama, Georgia, and Louisiana (Chang et al. 2009; Coneva et al. 2012; Ferguson et al. 2017; Parker et al. 2012). Rabbiteye blueberry is considered less susceptible to bacterial leaf scorch than southern highbush blueberry and is associated with less dramatic symptoms than those observed in some southern highbush cultivars (Brannen et al. 2016; Chang et al. 2009; Ferguson et al. 2017). However, in Louisiana, researchers found an association between $X$. fastidiosa infection and yield reduction (Ferguson et al. 2017).

$X$. fastidiosa has been reported from numerous wild and cultivated plants (EFSA 2018), but there is host specificity among strains of $X$. fastidiosa (Harris and Balci 2015; Nunney et al. 2013). Understanding the host range of strains is important (Hopkins and Purcell 2002), as host range is likely to impact the efficacy of disease management practices such as rogueing of alternative hosts and utilization of clean planting material. 
Within $X$. fastidiosa, there are two validly published subspecies (fastidiosa and multiplex) and at least four proposed subspecies (morus, pauca, sandyi, and tashke) (Bull et al. 2010; Nunney et al. 2014b; Randall et al. 2009; Schaad et al. 2004a, b; Schuenzel et al. 2005), although Marcelletti and Scortichini (2016) argue that strains previously classified as subspecies sandyi and morus actually belong in subsp. fastidiosa. Parker et al. (2012) and Van Horn et al. (2017) identified $X$. fastidiosa strains naturally occurring in blueberry as subsp. multiplex. When only one locus was compared, two isolates from blueberry were equally closely matched to strains identified as subsp. multiplex and subsp. sandyi (Nissen 2010; Nunney et al. 2013). Nunney et al. (2013) placed all seven $X$. fastidiosa isolates of blueberry origin that were included in their study into a group that, while considered to be part of subsp. multiplex, may have arisen from recombination with subsp. fastidiosa (Nunney et al. 2014a).

Scally et al. (2005) developed a multilocus sequence typing (MLST) scheme, modified by Yuan et al. (2010), which allows $X$. fastidiosa strains to be genotyped below the subspecies level. The MLST approach involves typing strains based on the exact nucleotide sequences at seven housekeeping loci (Scally et al. 2005). An additional locus, pilU, is sometimes utilized in conjunction with the MLST loci (Nunney et al. 2014a; Yuan et al. 2010). Parker et al. (2012) took a different multilocus approach to characterizing $X$. fastidiosa isolates, which they termed multilocus sequence analysis of environmentally mediated genes (MLSA-E). Their approach involved nine genes that had, on average, higher ratios of non-synonymous to synonymous substitution rates than those used in the Yuan et al. (2010) MLST scheme.

Seven blueberry isolates that have been typed by the MLST scheme have been identified as sequence type (ST) 42 or 43 , which were among strains that were deemed to be recombinant subsp. multiplex (Nunney et al. 2013). By the MLSA-E analysis of Parker et al. (2012), seven strains from blueberry, including one from rabbiteye blueberry, grouped together in what they called clade A of $X$. fastidiosa subsp. multiplex. Nunney et al. (2013) included 13 of the $21 X$. fastidiosa subsp. multiplex isolates (from blueberry and other hosts) used by Parker et al. (2012), and they found that the six that Parker et al. (2012) called clade A were all part of the group that Nunney et al. (2013) considered recombinant.
While these findings suggest the possibility that a narrow range of $X$. fastidiosa subsp. multiplex genotypes occur in naturally infected blueberry plants, southern highbush blueberry plants expressed symptoms of leaf scorch following inoculation with $X$. fastidiosa subsp. fastidiosa isolates from elderberry and lupine, as well as $X$. fastidiosa subsp. multiplex isolates from almond and blackberry (Hopkins et al. 2012). Oliver et al. (2015) found that four subsp. fastidiosa isolates from two species (grape and elderberry) were able to colonize southern highbush blueberry cultivar Rebel plants, although the symptoms they caused were less severe than those caused by two of three isolates of blueberry origin. Recently, Di Genova et al. (2019) reported natural and artificial infection of southern highbush blueberry plants in Georgia by subsp. fastidiosa.

The objective of this study was to determine what $X$. fastidiosa strains are found in rabbiteye blueberry plants. This relates to the practical questions of what plants might serve as alternative hosts for $X$. fastidiosa in rabbiteye blueberry and whether rabbiteye blueberry might serve as an alternative host of the bacterium for more susceptible southern highbush blueberry cultivars.

To determine what $X$. fastidiosa genotypes are found in rabbiteye blueberry, DNA extracted from the following sources was utilized for multilocus sequence typing: (i) X. fastidiosa isolate LA-Y3C cultured from a 'Tifblue' rabbiteye blueberry stem in an East Feliciana Parish, Louisiana, orchard, (ii) petiole/midrib tissue from 'Tifblue' rabbiteye blueberry plants from the same East Feliciana Parish orchard, and (iii) stem tissue of a rabbiteye blueberry plant from a Saint Landry Parish, Louisiana, orchard. Samples represented both of the two out of 17 Louisiana blueberry orchards sampled in which $X$. fastidiosa was detected (Ferguson 2016). All source plants had been confirmed as X. fastidiosa-positive by real-time PCR. DNA was subjected to PCR using primers for loci leuA, petC, malF, cysG, holC, $n u o L$, gltT, and pilU, based on the protocol outlined in Yuan et al. (2010). Between 0.7 and $5 \mu$ l of template DNA was used in each $25 \mu$ reaction.

PCR was performed on an Applied Biosystems 2720 Thermal Cycler (Life Technologies, Carlsbad, California, USA) using the following program: $3 \mathrm{~min}$ at $95^{\circ} \mathrm{C}$; 35 cycles of $30 \mathrm{~s}$ at $95^{\circ} \mathrm{C}, 30 \mathrm{~s}$ at $65^{\circ} \mathrm{C}$, and $1 \mathrm{~min}$ at $72{ }^{\circ} \mathrm{C}$; and $10 \mathrm{~min}$ at $72{ }^{\circ} \mathrm{C}$ (Yuan et al. 2010). A $1 \%$ agarose gel and GelRed stain (Biotium, Hayward, California, USA) were used to check for the presence of products of the expected sizes. Beckman Coulter 
Genomics (Danvers, Massachusetts, USA) or Macrogen USA (Rockville, Maryland, USA) sequenced PCR products using the Sanger method. Products were either purified prior to sending by using the QIAquick PCR Purification Kit (Qiagen, Valencia, California, USA) or purified using an enzymatic method by the company performing sequencing.

Forward and reverse sequences were aligned using MAFFT software (http://mafft.cbrc.jp/alignment/server/). In MAFFT or Mesquite (http://mesquiteproject.org), aligned forward and reverse sequences were viewed together and then assembled. Chromas (http://technelysium.com.au/wp/chromas/) was used to resolve conflicts between base calls. For the seven MLST loci, the sequences were entered as queries in the $X$. fastidiosa MLST database (http://pubmlst. org/xfastidiosa/), using the BLAST function. When assembled sequences differed from established alleles, MAFFT was used to determine where they differed. For pilU, sequences were entered into the NCBI BLAST query tool (https://blast.ncbi.nlm.nih.gov/Blast.cgi), and the matching pilU allele was noted.

When sequences from MLST loci and pilU of $X$. fastidiosa from culture and infected plant samples were BLASTed into the MLST database (for MLST loci) or NCBI database (for pilU), exact matches were revealed for most sequences, and close matches were found for others (Table 1). Sequences of one isolate and two plant tissue samples from the East Feliciana Parish orchard, as well as one from a Saint Landry Parish orchard, corresponded to the previously defined ST 42 and had pilU sequences identical to allele 9.

ST 42 was previously identified from blueberry in Georgia and from giant ragweed and western soapberry in Texas (Nunney et al. 2013). The latter two species, both native to the southern United States, are in the Asteraceae and Sapindaceae families, respectively. Other genotypes identified as ST 42 for which the nonMLST pilU locus identity was reported have also had pilU allele 9, as found in this study (Nunney et al. 2013).

Samples EF-H3 and EF-N3 shared some alleles with ST 42 but differed from it at two and four loci, respectively (Table 1). Two alleles, the gltT allele of EF-H3 and the $c y s G$ allele of EF-N3, did not match any that were previously defined in the MLST database. The EF-N3 cysG allele differed from alleles 12 and 14 by one base. The gltT sequence of EF-H3 was most similar to gltT allele 7 but differed at two bases. EF-H3 gltT and EF-N3 cysG alleles have been deposited in GenBank (accessions MG581179 and MG581180) and have been assigned allele numbers 16 and 33, respectively, in the MLST database (Table 1). The newly identified combinations of alleles were designated as STs 82 and 83 (Table 1).

Other than those newly established by this study, the alleles in STs 82 and 83 are found either in STs that, like STs 42 and 43, are believed to have resulted from recombination between $X$. fastidiosa subspecies multiplex and fastidiosa, or in both these and nonrecombinant $X$. fastidiosa subsp. multiplex strains (Nunney et al. 2013, 2014a, b; Yuan et al. 2010).

Table $1 X$. fastidiosa alleles at multilocus sequence typing (MLST) and pilU loci

\begin{tabular}{|c|c|c|c|c|c|c|c|c|c|c|}
\hline \multirow[b]{2}{*}{ Isolate or Plant ${ }^{\mathrm{a}}$} & \multirow[b]{2}{*}{ Location (Parish) } & \multicolumn{9}{|c|}{ Alleles $^{\mathrm{b}}$} \\
\hline & & $\operatorname{leu} A$ & petC & malF & $\operatorname{cys} G$ & holC & nuoL & gltT & pilU & $\mathrm{ST}^{\mathrm{b}}$ \\
\hline EF-C3 & East Feliciana & 6 & 3 & 5 & 12 & 4 & 3 & 3 & 9 & 42 \\
\hline EF-H3 & East Feliciana & 3 & 3 & 5 & 12 & 4 & 3 & $16^{\mathrm{c}}$ & 9 & $82^{\mathrm{c}}$ \\
\hline EF-K2 & East Feliciana & 6 & 3 & 5 & 12 & 4 & 3 & 3 & 9 & 42 \\
\hline EF-N3 & East Feliciana & 6 & 3 & 5 & $33^{c}$ & 7 & 4 & 7 & 9 & $83^{\mathrm{c}}$ \\
\hline LA-Y3C & East Feliciana & 6 & 3 & 5 & 12 & 4 & 3 & 3 & 9 & 42 \\
\hline SL-6 & St. Landry & 6 & 3 & 5 & 12 & 4 & 3 & 3 & 9 & 42 \\
\hline
\end{tabular}

${ }^{a}$ DNA sources were rabbiteye blueberry petiole/midrib tissue except for LA-Y3C (an isolate) and SL-6 (extracted from stem tissue)

${ }^{\mathrm{b}}$ Alleles (except those of pilU, which is not an MLST locus) and sequence types (ST) correspond to those in the $X$. fastidiosa MLST database (http://pubmlst.org/xfastidiosa/). Alleles also correspond to the following GenBank accessions: cysG $12=\mathrm{HM} 243602$, cys $G$ 14 = FJ610190, cysG 33 = MG581180, gltT $3=$ FJ610215, gltT 7 = FJ610220, gltT 16= MG581179, holC $4=$ FJ610196, holC $7=\mathrm{JX} 899403$, leuA 3= FJ610158, leuA 6 = JX899394, malF 5 = FJ610175, nuoL 3 = FJ610206, nuoL 4 = FJ610208, petC $3=$ FJ610167, pilU 9= JX899410

${ }^{\mathrm{c}}$ Alleles cysG 33 and gltT 16, as well as STs 82 and 83, were newly established based on this study 
Because our sequences were generated from plant samples, there is a possibility that more than one strain of $X$. fastidiosa was present, and isolation of the bacteria is needed to firmly establish the existence of new genotypes.

The alleles found in the EF-H3 sample (ST 82) were the same as those associated with ST 22, except that ST 22 has gltT allele 3 (Nunney et al. 2013). ST 22 has been identified from giant ragweed and western ragweed in Texas (Nunney et al. 2013). The alleles identified from EF-N3 (ST 83), except at the cys $G$ locus, are the same as those in ST 28, which has been identified from giant ragweed, annual sunflower, and seacoast sumpweed (Nunney et al. 2013). All of these ST 22 and ST 28 isolates came from Texas, where plants were collected around vineyards for $X$. fastidiosa isolation (Nunney et al. 2013). Additional efforts to type $X$. fastidiosa from wild plants might reveal that these STs are present in other species.

A limited number of $X$. fastidiosa STs have been identified from rabbiteye blueberry. However, considering that ST 42 has been found in giant ragweed and that recombinant genotypes similar to others identified from rabbiteye blueberry have been found in this and other Asteraceae family plants, the number of alternative hosts for strains of $X$. fastidiosa that infect blueberry may be considerable. Weed management compatible with good production practices could help minimize alternative hosts in the immediate vicinity of blueberry plants. Additional work to determine the sequence types of $X$. fastidiosa in wild plants would provide more insight on the likelihood of being able to aid management of $X$. fastidiosa by targeting certain plant species for removal. If it were determined that a limited number of common wild plants host genotypes of $X$. fastidiosa that infect blueberry, management of these could be prioritized. Costa et al. (2004) made a similar recommendation after identifying a limited number of wild plants as hosts of $X$. fastidiosa around vineyards in California.

The finding of ST 42 in rabbiteye blueberry does suggest that rabbiteye blueberry may serve as an alternative host of strains that are able to infect susceptible southern highbush blueberry cultivars. There may be strains of $X$. fastidiosa, however, that are identical at MLST loci but have differences at other loci that influence their abilities to infect certain hosts. Crossinoculation studies might add some clarity regarding the cross-infectivity of isolates from rabbiteye and southern highbush blueberry plants. Considering that older rabbiteye plants do not always show distinctive symptoms of $X$. fastidiosa infection (Ferguson et al. 2017), growers are advised to take care to use clean planting stock when introducing rabbiteye plants into orchards in which susceptible southern highbush cultivars are grown.

Acknowledgements The cooperation of participating blueberry growers, advice provided by Vinson Doyle, and contributions by Phil Brannen, Rock Christiano, Renee Holland, Mary Hoy, Rebecca Melanson, Emily Ringelman, Randy Sanderlin, Harald Scherm, Raj Singh, and the late Don Ferrin are gratefully acknowledged. Financial support was provided by Louisiana State University College of Agriculture, the LSU AgCenter, and Hatch funds from the United States Department of Agriculture, National Institute of Food and Agriculture. The use of trade, firm, or corporation names in this publication is for the information and convenience of the reader. Such use does not constitute an official endorsement or approval by the United States Department of Agriculture or the Agricultural Research Service of any product or service to the exclusion of others that may be suitable. This article is based on parts of the first author's Ph.D. dissertation.

\section{Compliance with ethical standards}

Conflict of interest The authors declare that they have no conflict of interest.

Ethical statement The research reported in this article did not have human or animal subjects.

Open Access This article is licensed under a Creative Commons Attribution 4.0 International License, which permits use, sharing, adaptation, distribution and reproduction in any medium or format, as long as you give appropriate credit to the original author(s) and the source, provide a link to the Creative Commons licence, and indicate if changes were made. The images or other third party material in this article are included in the article's Creative Commons licence, unless indicated otherwise in a credit line to the material. If material is not included in the article's Creative Commons licence and your intended use is not permitted by statutory regulation or exceeds the permitted use, you will need to obtain permission directly from the copyright holder. To view a copy of this licence, visit http://creativecommons.org/licenses/by/4.0/.

\section{References}

Brannen, P. M., Krewer, G., Boland, B., Horton, D., \& Chang, C. J. (2016). Bacterial leaf scorch of blueberry. University of Georgia Cooperative Extension Circular 922. http://extension.uga.edu/publications/files/pdf/C\%20922_4. PDF. Accessed 7 July 2019.

Bull, C. T., De Boer, S. H., Denny, T. P., Firrao, G., Fischer-Le Saux, M., Saddler, G. S., Scortichini, M., Stead, D. E., \& 
Takikawa, Y. (2010). Comprehensive list of names of plant pathogenic bacteria, 1980-2007. Journal of Plant Pathology, 92, 551-592.

Chang, C. J., Donaldson, R., Brannen, P., Krewer, G., \& Boland, R. (2009). Bacterial leaf scorch, a new blueberry disease caused by Xylella fastidiosa. HortScience, 44, 413-417.

Coneva, E. D., Murphy, J. F., \& Vinson, E. (2012). Incidence of Xylella fastidiosa in commercial blueberry orchards in Alabama. (Abstr.). HortScience, 47, S56.

Costa, H. S., Raetz, E., Pinckard, T. R., Gispert, C., HernandezMartinez, R., Dumenyo, C. K., \& Cooksey, D. A. (2004). Plant hosts of Xylella fastidiosa in and near southern California vineyards. Plant Disease, 88, 1255-1261.

Di Genova, D., Lewis, K., \& Oliver, J. E. (2019). Identification of Xylella fastidiosa subsp. fastidiosa from infected southern highbush blueberry (Vaccinium sp.) in Georgia. (Abstr.). Phytopathology, 109, S1.5. https://doi.org/10.1094 /PHYTO-109-9-S1.1.

EFSA (European Food Safety Authority). (2018). Scientific report on the update of the Xylella spp. host plant database. EFSA Journal, 16(9), 5408. https://doi.org/10.2903/j. efsa.2018.5408.

Ferguson, M. H. (2016). Characterization of Xylella fastidiosa in rabbiteye blueberry. Baton Rouge: Ph.D. dissertation, Louisiana State University.

Ferguson, M. H., Clark, C. A., \& Smith, B. J. (2017). Association of Xylella fastidiosa with yield loss and altered fruit quality in a naturally infected rabbiteye blueberry orchard. HortScience, 52, 1073-1079.

Harris, J. L., \& Balci, Y. (2015). Population structure of the bacterial pathogen Xylella fastidiosa among street trees in Washington D.C. PLoS One, 10, e0121297. https://doi. org/10.1371/journal.pone.0121297.

Hopkins, D. L., \& Purcell, A. H. (2002). Xylella fastidiosa: Cause of Pierce's disease of grapevine and other emergent diseases. Plant Disease, 86, 1056-1066.

Hopkins, D., Harmon, P., \& Brannen, P. (2012). Host range of Xylella fastidiosa strains that cause blueberry leaf scorch. (Abstr.). Phytopathology, 102, S4.55.

Marcelletti, S., \& Scortichini, M. (2016). Genome-wide comparison and taxonomic relatedness of multiple Xylella fastidiosa strains reveal the occurrence of three subspecies and a new Xylella species. Archives of Microbiology, 198, 803-812.

Nissen, L. D. (2010). Characterization of Xylella fastidiosa strains that cause bacterial leaf scorch of southern highbush blueberry (Vaccinium corymbosum interspecific hybrids), and the detection of the pathogen in plants and glassy-winged sharpshooters [Homalodisca vitripennis (Germar)] (Hemiptera: Cicadellidae) in South Georgia. Athens, GA: M.S. thesis, University of Georgia.

Nunney, L., Vickerman, D. B., Bromley, R. E., Russell, S. E., Hartman, J. R., Morano, L. D., \& Stouthamer, R. (2013). Recent evolutionary radiation and host plant specialization in the Xylella fastidiosa subspecies native to the United States. Applied and Environmental Microbiology, 79, 2189-2200.
Nunney, L., Hopkins, D. L., Morano, L. D., Russell, S. E., \& Stouthamer, R. (2014a). Intersubspecific recombination in Xylella fastidiosa strains native to the United States: Infection of novel hosts associated with an unsuccessful invasion. Applied and Environmental Microbiology, 80, 1159-1169.

Nunney, L., Schuenzel, E. L., Scally, M., Bromley, R. E., \& Stouthamer, R. (2014b). Large-scale intersubspecific recombination in the plant-pathogenic bacterium Xylella fastidiosa is associated with the host shift to mulberry. Applied and Environmental Microbiology, 80, 3025-3033.

Oliver, J. E., Cobine, P. A., \& De La Fuente, L. (2015). Xylella fastidiosa isolates from both subsp. multiplex and fastidiosa cause disease on southern highbush blueberry (Vaccinium sp.) under greenhouse conditions. Phytopathology, 105, $855-862$.

Parker, J. K., Havird, J. C., \& De La Fuente, L. (2012). Differentiation of Xylella fastidiosa strains via multilocus sequence analysis of environmentally mediated genes (MLSA-E). Applied and Environmental Microbiology, 78, 1385-1396.

Randall, J. J., Goldberg, N. P., Kemp, J. D., Radionenko, M., French, J. M., Olsen, M. W., \& Hanson, S. F. (2009). Genetic analysis of a novel Xylella fastidiosa subspecies found in the southwestern United States. Applied and Environmental Microbiology, 75, 5631-5638.

Scally, M., Schuenzel, E. L., Stouthamer, R., \& Nunney, L. (2005). Multilocus sequence type system for the plant pathogen Xylella fastidiosa and relative contributions of recombination and point mutation to clonal diversity. Applied and Environmental Microbiology, 71, 8491-8499.

Schaad, N. W., Postnikova, E., Lacy, G., Fatmi, M., \& Chang, C. J. (2004a). Erratum: Xylella fastidiosa subspecies: $X$. fastidiosa subsp. piercei, subsp. nov., $X$. fastidiosa subsp. multiplex subsp. nov., and X. fastidiosa subsp. pauca subsp. nov. Systemic and Applied Microbiology, 27, 763.

Schaad, N. W., Postnikova, E., Lacy, G., Fatmi, M., \& Chang, C. J. (2004b). Xylella fastidiosa subspecies: X. fastidiosa subsp. piercei, subsp. nov., $X$. fastidiosa subsp. multiplex subsp. nov., and $X$. fastidiosa subsp. pauca subsp. nov. Systemic and Applied Microbiology, 27, 290-300.

Schuenzel, E. L., Scally, M., Stouthamer, R., \& Nunney, L. (2005). A multigene phylogenetic study of clonal diversity and divergence in north American strains of the plant pathogen Xylella fastidiosa. Applied and Environmental Microbiology, 71, 3832-3839.

Van Horn, C., Chang, C. J., \& Chen, J. (2017). De novo wholegenome sequence of Xylella fastidiosa subsp. multiplex strain $\mathrm{BB} 01$ isolated from a blueberry in Georgia, USA. Genome Announcements, 5, e01598-e01516. https://doi.org/10.1128 /genomeA.01598-16.

Yuan, X., Morano, L., Bromley, R., Spring-Pearson, S., Stouthamer, R., \& Nunney, L. (2010). Multilocus sequence typing of Xylella fastidiosa causing Pierce's disease and oleander leaf scorch in the United States. Phytopathology, 100, 601-611. 